\title{
Research on the Export Potential of China's Equipment Manufacturing Products to Countries Along the Belt and Road
}

\author{
Pengfei Chu ${ }^{1}$, Guanxia $\mathrm{Xie}^{2} \&$ Zhenyun $\mathrm{Liu}^{3}$ \\ ${ }^{1}$ School of Economics and Management, South China Normal University, Guangzhou, China \\ ${ }^{2}$ School of Economics, Jinan University, Guangzhou, China \\ ${ }^{3}$ School of Economics and Trade, Guangdong University of Foreign Studies, Guangzhou, China \\ Correspondence: Guanxia Xie, School of Economics, Jinan University, Tianhe Ave., Guangzhou 510632, China. \\ E-mail:pfchu@outlook.com
}

Received: August 11, 2020

Accepted: September 4, $2020 \quad$ Online Published: September 28, 2020

doi:10.5539/ijef.v12n10p105

URL: https://doi.org/10.5539/ijef.v12n10p105

\begin{abstract}
Based on China's export trade data of equipment manufacturing to countries along the Belt and Road from 2006 to 2018 , this paper uses a stochastic frontier gravity model to analyze the influencing factors and export trade efficiency of China's export trade. The results indicate that: 1) Larger economic scale and population size, closer geographical distance, common boundaries and a common language can significantly increase China's exports of equipment manufacturing products to countries along the route. 2) Signing free trade agreements with partners, increasing trade openness, and improving infrastructure construction can significantly improve China's export trade level, while excessive tariff levels will inhibit export trade efficiency. 3) In recent years, the efficiency of China's export trade to countries along the Belt and Road has improved, but the overall level is still low, and the efficiency of export trade to different countries varies greatly. Therefore, it is necessary to strengthen international trade cooperation, improve conditions for trade development, increase investment in infrastructure construction with countries along the Belt and Road, and adopt targeted strategies for different types of markets to develop market potential.
\end{abstract}

Keywords: manufacturing export, trade efficiency, trade potential, stochastic frontier gravity model

\section{Introduction}

Manufacturing is a pillar industry of China's national economy, and equipment manufacturing is a strategic industry of the country. Statistics from the United Nations show that, China's exports of equipment manufacturing to countries along the Belt and Road reached $\$ 13,99.252$ in 2018, which is more than half of China's total exports of goods to the world during the same period. There are 65 countries in the Belt and Road Initiative, with a population of $65 \%$ of the global total, which is an international market worth exploring. After the Belt and Road initiative was put forward, the frequency of trade links between China and countries along the route has increased year by year, and the scale of trade has continued to expand. The economies of the member states have developed steadily and rapidly, and China's domestic industries have also developed in a balanced manner. To continue to expand the Belt and Road market in the future, we need to study the following questions: Has China's current export trade volume of equipment manufacturing products to countries along the Belt and Road reach the maximum export potential? What factors restrict China's export trade volume and export trade efficiency?

Many scholars have studied the trade relationship between China and the countries along the Belt and Road, but most of the existing literature discusses trade potential and trade efficiency from the perspective of general trade in goods or specific regions. There are relatively few studies on the trade potential of equipment manufacturing between China and countries along the route. The researches on the equipment manufacturing industry are mostly conducted from the global value chain and the integration of the producer service industry, while the research from the macro level, especially the international perspective, is relatively rare. The development of the equipment manufacturing industry can strengthen infrastructure construction and accelerate the realization of economic integration. The countries along the Belt and Road have great demand for energy and basic equipment, which will promote China's equipment manufacturing industry to the world. 
In this context, based on the stochastic frontier gravity model, this paper uses the "one-step method" to analyze the factors affecting China's export trade and export efficiency of equipment manufacturing products from countries along the Belt and Road. It also measured China's export trade efficiency and export potential to various countries. Finally, the paper puts forward suggestions on expanding the scale of foreign trade and improving trade efficiency. The reminder of the paper is structured as follows. Section 2 introduces the existing studies in related fields. Section 3 introduces the model, variables and data sources. Section 4 carries out empirical analyses and presents the results. The paper concludes with policy recommendations in Section 5.

\section{Literature Review}

\subsection{Application of Gravity Models}

The traditional gravity model of trade expresses that the total trade volume and GDP of the two regions are positively correlated, while the distance is negatively correlated. Isard and Peck (1954) and Beckerman (1956) found that the trade flows between countries are regular, and the closer the distance between countries, the larger the trade scale. Tinbergen (1962) and Poyhonen (1963) were the first economists to introduce this physical concept to the science of trade, and then Linnemann (1966) incorporated the demographic factor on the basis of existing research. Since then, the gravity model has developed rapidly in economics. Scholars consider various control variables according to the research objects, such as colonial relations, trade preference agreements, common borders, and language.

The gravity model has emerged as a widely employed approach to estimate the trade potential. Kalirajan (1999) defines trade potential as the maximum trade volume that can be achieved when trade is fully opened under the current conditions of trade, transportation and institutional technology. Subsequently, scholars such as Nilsson (2000) and Fuchs and Wohlrabe (2005) measured and analyzed the trade potential of different regions on the basis of this concept.

However, the traditional gravity model is also not perfect. Many unmeasured but trade-related factors are unified into the random error items, such as policy environment, rules and regulations. In order to improve the traditional gravity model of trade, Armstrong (2007) combined trade science with microeconomics and proposed the "stochastic frontier gravity model" with reference to the "frontier" concept in the production function. The model regards trade potential as the highest level that trade can reach without any friction.

Since this model can consider human obstacles, it has been widely used. For example, Ravishankar and Stack (2014) uses the stochastic frontier model to study the trade potential of Eastern Europe, and Viorica (2015) and Tamini (2016) study the trade potential and trade efficiency of EU member states and North African countries. There are also many related studies in China. Lu and Zhao (2010) found that China's exports are in a low-efficiency state, indicating that China does have a large export potential.

\subsection{Trade Potential between China and the Belt and Road Countries}

In recent years, research on the trade potential and efficiency between China and the countries along the Belt and Road has become a hot topic. Most literature believes that my country's trade with countries or regions along the road is inefficient and has great trade potential (Wang \& Wu, 2016; Zhang, 2017; Hou \& Deng, 2017; Zong et al., 2018). Existing research is mainly carried out from the following perspectives:

The export potential of China and all countries along the Belt and Road. Wang (2017) found that China has a trade non-item rate phenomenon in the process of exporting to countries along the route, and the trade non-item rate is mainly affected by terms of trade and government efficiency. Tang et al. (2018) measured the export potential of 61 countries along the Belt and Road, and divided these countries into potential remodeling, pioneering and huge based on their potential value. Zhang and Yin (2018) believe that China's exports to countries along the route have been increasing year by year, but trade inefficiency factors limit the export potential.

The export potential of specific countries or regions in China and the Belt and Road Initiative. Gao et al. (2015) analyzed the efficiency of bilateral trade and export trade between China and Pakistan based on the time-varying stochastic frontier model, and found that the efficiency of bilateral trade was significantly lower than that of export, which also indicated that the export potential was relatively low. Some scholars analyze export potential from the perspective of ideological distance. Wang (2020) took the Middle East and North Africa as the research object and found that the institutional distance has a "critical value" effect, and the greater the gap between China and a country with an institutional gap, the greater the room for increasing export potential

The export potential of specific export products between China and the Belt and Road countries. Li (2017) believes that Arab countries have strong demand for high-tech products, and China has great potential to export 
such products to them. $\mathrm{Li}$ and $\mathrm{Lu}$ (2019) used a two-step method to measure the export potential of the equipment manufacturing industry. Yin and Liu (2019) pointed out that the export potential of electrical equipment manufacturing products is still great. Dang and Zhao (2020) focused on the analysis of the factors affecting agricultural trade between China and more than 20 countries along the road, and found that agricultural exports are low in efficiency and have great potential.

In summary, scholars conducted a great deal of studies on the trade between China and countries along the Belt and Road, but there are still some aspects can be improved: First of all, most scholars study the bilateral potential and efficiency between China and the countries along the Belt and Road from the perspective of trade in goods, but there are relatively few articles on export potential. Secondly, the equipment manufacturing industry is very important to the development of the country, but the current literature on China and the Belt and Road countries is concentrated in the field of agricultural products, while the literature on the equipment manufacturing industry is relatively scarce. Finally, most studies use traditional gravity models to analyze bilateral trade flows and measure trade potential. But the traditional gravity model fails to reflect the resistance factors of trade efficiency. Although some scholars use the stochastic frontier method, they mostly use the "two-step method" to estimate the parameters, which makes the parameter estimation biased. Based on the equipment manufacturing data of China and the countries along the Belt and Road, this paper uses the stochastic frontier gravity model to empirically analyze the factors that affect the scale of export trade and the inefficiency of export trade through the "one-step method", and analyze China's export trade efficiency and export potential.

\section{Model, Variables and Methodology}

\subsection{Empirical Model}

The traditional gravity model incorporates many unmeasured factors into the random disturbance term, which makes the parameter estimation biased. Therefore, more scholars use the stochastic frontier gravity model to analyze trade potential and efficiency. This model overcomes the limitations of the traditional gravity model, replacing the disturbance term in the original model with independent random error terms and trade inefficiency terms. Assuming that the actual trade volume from country $i$ to country $j$ in year $\mathrm{t}$ is $T_{i j t}$, the export potential can be calculated according to the stochastic frontier gravity model as:

$$
T^{*}{ }_{i j t}=f\left(x_{i j t}, \beta\right)
$$

In Equation 1, $x_{i j t}$ refers to factors that affect trade exports, such as economic scale, geographic distance, and population size, etc., $\beta$ is the parameter to be estimated, $T^{*}{ }_{i j t}$ represents the export potential of country $i$ to country $j$ in year $t$. Due to export resistance and random factors, the actual trade export quantity cannot reach the maximum (export potential), so the actual export volume is:

$$
T_{i j t}=f\left(x_{i j t}, \beta\right) \exp \left(v_{i j t}\right) \exp \left(-u_{i j t}\right)
$$

In Equation 2, $v_{i j t}$ represents the random measurement error that obeys the normal distribution, $u_{i j t}$ represents trade inefficiency, usually assumed to be half normal distribution, gamma distribution, etc., $T_{i j t}$ represents the actual export value. When $u_{i j t}>0$, it means that there are some obstacles in the trade process, which makes the actual trade value not reach the maximum potential trade value, while $u_{i j t}=0$ indicates that the trade has reached the trade frontier level. Further, the export trade efficiency can be expressed as:

$$
T E_{i j t}=\frac{T_{i j t}}{T^{*} i j t}=\exp \left(-u_{i j t}\right)
$$

In Equation 3, $T E_{i j t}$ represents the efficiency of export trade, which is the ratio of actual export value to potential export value (export potential). When $u_{i j t}=0$, the actual export value is equal to the potential export value, and the export trade efficiency is 1 . when $u_{i j t}>0$, there is an inefficiency item in trade, the actual export value is less than the potential export value, and the export trade efficiency is between 0 and 1 .

After measuring the export trade efficiency according to the stochastic frontier gravity model, the export potential can be expressed as:

$$
T^{*}{ }_{i j t}=\frac{T_{i j t}}{T E_{i j t}}
$$

The main purpose of the stochastic frontier model is to measure efficiency and study the factors affecting efficiency. Early literature mostly used a two-step method for estimation, also known as the "split method" (Reifschnieder \& Stevenson, 1991): First, obtain the estimated value of efficiency according to the stochastic 
frontier model, and then construct the function that may affect the efficiency. But the two-step method has drawbacks, such as:

The two-step method usually assumes that the variables used to estimate the efficiency in the first step have nothing to do with the variables that affect the efficiency in the second step. Under this premise, the efficiency value estimated by the maximum likelihood method is unbiased. However, in reality the two are likely to be related.

In the first step, it is assumed that the inefficiency term $u$ is independent and identically distributed, but in the second step, TE is used as a dependent variable and changes with a series of exogenous variables, which means that $u$ does not satisfy independent and identical distribution.

In view of this, Battese and Coelli (1995) proposed the bc95 model, which opened the prelude to the application of the "one-step method". Wang and Schmidt (2002) using Monte Carlo method also confirmed that the one-step estimation method is better than the two-step method. Therefore, this paper also chooses the "one-step method" to estimate the stochastic frontier gravity model.

\subsection{Variables}

This article draws on the setting of Armstrong (2007) on the stochastic frontier gravity model. When estimating the trade frontier, it adds key variables such as GDP, geographic distance, language, and border, including:

1) Economic scale. Countries with high GDP have strong export capacity, so GDP has a positive effect on trade.

2) Geographical distance. Countries with closer geographical distances have lower transportation costs and more frequent trade.

3) Population size. There is uncertainty about the role of the population size of the two countries on the volume of trade. For exporting countries, the increase in population can provide their external supply capacity, but their own domestic demand will also increase. When the domestic supply capacity can meet their own needs, export trade can increase. For importing countries, an increase in the size of the population means increased productivity, and imports will decrease. However, as domestic demand increases, the country may also seek to alleviate the problem of insufficient supply by seeking imports.

4) Common language. Having a common language can reduce the cost of communication between countries and promote trade development. This paper sets the common language as a dummy variable. If the languages of the two countries are the same, this variable is 1 , otherwise, it is 0 .

5) Common boundary. From the perspective of transportation costs, it is easier for the two countries to trade if they have a common boundary. In this paper, the common boundary is set as a dummy variable. If the two countries have a common boundary, this variable is 1 , otherwise it is 0 .

6) Whether it is a landlocked country. Generally speaking, landlocked countries have higher transportation costs and smaller trade volume. This article sets whether the country is landlocked as a dummy variable. If the country along the route is a landlocked country, this variable is 1 , otherwise it is 0 .

When analyzing the influencing factors of export efficiency, this article considers the five dimensions of the institutional environment, free trade agreements, tariff levels, trade openness and infrastructure. The specific measurement indicators are as follows:

1) Institutional environment. It is generally believed that a good institutional environment is conducive to promoting the development of bilateral trade. This paper uses political stability indicators and government efficiency indicators to measure the institutional environment. These two indicators reflect the administrative barriers of a country's participation in international trade. The higher the value, the stronger the country's political stability and the higher the government's office efficiency.

2) Free trade agreements. The signing of a trade agreement between the two countries will help promote trade development. This article sets the free trade agreement as a dummy variable. If the free trade agreement between China and the countries along the Belt and Road takes effect, the variable is recorded as 1, otherwise it is 0 .

3) Tariff level. Higher tariffs will increase the cost of trade, which is not conducive to the development of trade. This article uses the "weighted average applicable tax rate for all products" to measure the tariff level.

4) Trade openness. The degree of trade openness reflects the proportion of a country's trade volume in its GDP. The larger the value, the higher the dependence on foreign markets, which can promote the development of bilateral trade.

5) Infrastructure. Complete infrastructure can reduce trade costs, increase trade facilitation, and thus increase 
trade efficiency. This article uses transportation and communication infrastructure to measure the level of infrastructure construction in a country. Transportation infrastructure is measured by liner connectivity index, and communication infrastructure is measured by Internet penetration rate, which can better reflect the opportunities and dividends brought by the Internet.

Table 1. Variables description

\begin{tabular}{|c|c|c|}
\hline & Variables & Variables contents \\
\hline \multirow{7}{*}{$\begin{array}{l}\text { Explanatory variables affecting the } \\
\text { frontier of export trade }\end{array}$} & $P G D P_{j t}$ & GDP of country $\mathrm{j}$ in year $\mathrm{t}$ \\
\hline & $C G D P_{i t}$ & China's GDP in year $\mathrm{t}$ \\
\hline & $P O P C_{i t}$ & Total population of China in year $t$ \\
\hline & $P O P_{j t}$ & Total population of country $\mathrm{j}$ in year $\mathrm{t}$ \\
\hline & Dist $_{i j}$ & Distance between China and the capital of country $j$ \\
\hline & Border $_{i j}$ & Does country j border China \\
\hline & Lang $_{i j}$ & Does country $\mathrm{j}$ have a common language with China \\
\hline \multirow{7}{*}{$\begin{array}{l}\text { Explanatory variables affecting } \\
\text { inefficiency }\end{array}$} & $s t a_{j t}$ & Political stability index of country $\mathrm{j}$ in year $\mathrm{t}$ \\
\hline & $\operatorname{pro}_{j t}$ & China's government efficiency indicators in year $t$ \\
\hline & $F T A_{i j}$ & Whether country $\mathrm{j}$ has signed a free trade agreement with China \\
\hline & $\operatorname{tax}_{j t}$ & The tariff level of country $\mathrm{j}$ in year $\mathrm{t}$ \\
\hline & $t o i_{j t}$ & Trade openness of country $\mathrm{j}$ in year $\mathrm{t}$ \\
\hline & $n e t_{j t}$ & Internet penetration rate in country $\mathrm{j}$ in year $\mathrm{t}$ \\
\hline & $\operatorname{ship}_{j t}$ & Liner connectivity index of country $\mathrm{j}$ in year $\mathrm{t}$ \\
\hline
\end{tabular}

\subsection{Data and Sources}

There is no uniformly defined scope along the One Belt One Road. At present, the academic circles generally divide the scope of the One Belt One Road into six major plates: Central Asia, Southeast Asia, Central and Eastern Europe, South Asia, West Asia and North Africa, and the Commonwealth of Independent States. Based on the availability of data, this paper sets the sample scope to 58 countries including Kazakhstan and Kyrgyzstan, and the time span is 2006-2018 (Note 1).

Data on the export value of China's equipment manufacturing products to countries along the Belt and Road are derived from the UN Comtrade Database. GDP data comes from the World Bank's World Development Indicators Database (WDI), calculated in USD at constant prices in 2020. The distance, border, language, and inland data are found in the French Center for International Economic Research (CEPII). In the trade inefficiency model, the free trade agreement signing data comes from the RTA database. The data on trade openness, Internet penetration rate and liner connectivity index come from the United Nations Conference on Trade and Development (UNCTAD).The data for political stability indicators and government efficiency indicators come from the Worldwide Governance Indicators issued by the World Bank.

\subsection{Methodology}

Based on the "one-step method" model proposed by Battese and Coelli (1995) and referring to the design in the traditional gravity model, this paper constructs a model of China's export potential for equipment manufacturing products in countries along the Belt and Road. Among them, he trade frontier model of export trade is set as follows:

$$
\begin{gathered}
E X_{i j t}=\beta_{0}+\beta_{1} P G D P_{j t}+\beta_{2} C G D P_{i t}+\beta_{3} P O P C_{i t}+\beta_{4} P O P_{j t}+\beta_{5} \text { Dist }_{i j}+\beta_{6} \text { Border }_{i j}+\beta_{7} \text { Lang }_{i j}+ \\
\beta_{8} \text { Land }_{j}+v_{i j t}-u_{i j t}
\end{gathered}
$$

$E X_{i j t}$ represents China's export trade volume of equipment manufacturing products from countries along the Belt and Road. Subscript $i$ represents China, subscript $j$ represents the trading partner country, and $t$ represents the year. The meanings of other variables are shown in Table 1. PGDP $P_{j t}, C G D P_{i t}, P O P C_{i t}, P O P_{j t}$ and $D i s t_{i j}$ all take the logarithm.

In the trade non-term rate model, the institutional environment, trade openness level, trade agreement, tariff level, and infrastructure are used as explanatory variables to analyze trade resistance factors. The specific model is set as follows:

$$
\begin{gathered}
u_{i j t}=\delta Z_{i j t}+\varepsilon_{i j t} \\
Z_{i j t}=\left(\text { sta }_{j t}, \text { pro }_{j t}, \text { FTA }_{i j t}, \text { tax }_{j t} \text { toi }_{j t}, \text { net }_{j t}, \text { ship }_{j t}\right) \\
u_{i j t}=\alpha_{0}+\alpha_{1} \text { sta }_{j t}+\alpha_{2} \text { pro }_{j t}+\alpha_{3} F T A_{i j}+\alpha_{4} \text { tax }_{j t}+\alpha_{5} \text { toi }_{j t}+\alpha_{6} n e t_{j t}+\alpha_{7} \text { ship }_{j t}+\varepsilon_{i j t}
\end{gathered}
$$


Equation (6) represents the trade inefficiency item. Equation (7) lists the factors that may affect the inefficiency item. Equation (8) is the complete trade inefficiency item model.

\section{Empirical Result}

\subsection{Likelihood Ratio Test}

This paper uses likelihood ratio test to analyze the applicability of the stochastic frontier gravity model and the specific form of the equation. The results are shown in Table 2. The likelihood ratio test result in the first step shows that the trade inefficiency effect exists, which means that the stochastic frontier gravity model is applicable. The second test shows that the time-varying stochastic frontier gravity model should be used. The test results of the third to sixth steps show that the four variables of geographic distance, boundary, language, and inland should all be placed in the model.

Table 2. Likelihood ratio test results

\begin{tabular}{cccccc}
\hline Null Hypothesis & Constrained Model & Unconstrained model & LR Statistics & $5 \%$ threshold & test results \\
\hline No trade inefficiency & -756.42 & -604.51 & 303.82 & 7.82 & Refuse \\
Trade inefficiency is constant & -345.62 & -309.72 & 71.8 & 3.84 & Refuse \\
No geographic distance & -299.98 & -309.72 & 19.48 & 3.84 & Refuse \\
No boundary variables & -607.77 & -604.51 & 6.52 & 3.84 & Refuse \\
No language variables & -608.63 & -604.51 & 8.24 & 3.84 & Refuse \\
No Inland variables & -608.70 & -604.51 & 8.38 & 3.84 & Refuse \\
\hline
\end{tabular}

\subsection{Results Analyses}

The article uses the "one-step method" to estimate the parameters. For the convenience of comparison, we also give the estimation results based on OLS, time-invariant model and time-varying model, as shown in Table 3. The four columns in the table are: regression results based on OLS, estimation results of non-time-varying inefficiency model using bc 88 model, estimation results of time-varying non-efficiency model using bc 92 , and estimation results based on bc95. According to the estimation result of the bc95 model, it can be found that $\gamma$ is relatively close to 1 , indicating that the trade inefficiency is the main reason why the actual trade value cannot reach the potential trade value.

The economic scale variables PGDP and CGDP are both significant, indicating that increasing the economic level of the countries along the Belt and Road and China's economic level can stimulate the export of Chinese equipment manufacturing products. The total population index of the countries along the route is positive but not significant. This may be because most of the countries along the road have much smaller populations than China, and their positive effects are not fully reflected. The POPC of China's total population is significantly negative, indicating that the population growth of exporting countries will inhibit the development of export trade. This may be because the population growth of exporting countries will increase domestic demand, while domestic output growth is relatively slow, unable to meet both the international and domestic demand markets. In this case, China will give priority to meeting domestic demand and reduce exports. The coefficient of geographic distance is significantly negative, indicating that the farther China's geographic distance from its partner countries, China's export trade to it will significantly decrease. The coefficients of the common border and common language are both significantly positive, indicating that the two countries have a common border and a common language can significantly increase China's exports of equipment manufacturing products to countries along the road.

Table 3. Empirical regression results

\begin{tabular}{ccccc}
\hline & $(1)$ & $(2)$ & $(3)$ & $(4)$ \\
\hline Inpgdp & OLS & bc88 & bc92 & bc95 \\
& $0.714^{* * *}$ & $0.894^{* * *}$ & $1.049^{* * *}$ & $0.946^{* * *}$ \\
lncgdp & $(16.63)$ & $(9.28)$ & $(25.51)$ & $(15.77)$ \\
& $4.755^{* * *}$ & $4.748^{* * *}$ & $4.721^{* * *}$ & $4.179^{* * *}$ \\
lnpop & $(4.15)$ & $(13.54)$ & $(102.37)$ & $(6.92)$ \\
& $-0.192^{* * *}$ & -0.022 & -0.063 & 0.088 \\
lnpopc & $(4.43)$ & $(-0.21)$ & $(-0.87)$ & $(1.40)$ \\
& $-60.317^{* * *}$ & $-60.889^{* * *}$ & $-61.432^{* * *}$ & $-57.441^{* * *}$ \\
\hline
\end{tabular}




\begin{tabular}{|c|c|c|c|c|}
\hline lndist & $\begin{array}{c}-0.795^{* * *} \\
(-4.67)\end{array}$ & $\begin{array}{c}-1.142^{* * *} \\
(-1.99)\end{array}$ & $\begin{array}{c}-0.986^{* * *} \\
(-3.60)\end{array}$ & $\begin{array}{c}-1.110^{* * * *} \\
(-9.58)\end{array}$ \\
\hline border & $\begin{array}{l}-0.284^{* *} \\
(-2.10)\end{array}$ & $\begin{array}{l}-0.127 \\
(-0.27)\end{array}$ & $\begin{array}{l}0.371 \\
(1.57)\end{array}$ & $\begin{array}{l}0.195^{* *} \\
(2.51)\end{array}$ \\
\hline lang & $\begin{array}{l}0.414^{*} \\
(1.86)\end{array}$ & $\begin{array}{l}0.127 \\
(2.67)\end{array}$ & $\begin{array}{c}0.902^{* * *} \\
(3.21)\end{array}$ & $\begin{array}{c}0.524^{* * *} \\
(5.45)\end{array}$ \\
\hline land & $\begin{array}{l}-0.103 \\
(-1.03)\end{array}$ & $\begin{array}{l}-0.093 \\
(-0.27)\end{array}$ & $\begin{array}{c}0.326^{* * *} \\
(2.73)\end{array}$ & $\begin{array}{c}0.193^{* * *} \\
(2.91)\end{array}$ \\
\hline cons & $\begin{array}{c}621.961^{* * * *} \\
(3.20)\end{array}$ & $\begin{array}{c}633.256^{* * * *} \\
(10.59)\end{array}$ & $\begin{array}{c}634.719^{* * *} \\
(637.16)\end{array}$ & $\begin{array}{c}600.755^{* * *} \\
(5.95)\end{array}$ \\
\hline$\sigma^{\wedge} 2$ & & 1.129 & 1.408 & 0.328 \\
\hline $\begin{array}{c}\gamma \\
\text { sta }\end{array}$ & & 0.911 & 0.930 & $\begin{array}{c}0.892 \\
-0.018 \\
(-0.48)\end{array}$ \\
\hline pro & & & & $\begin{array}{l}-0.022 \\
(-0.34)\end{array}$ \\
\hline FTA & & & & $\begin{array}{c}-0.292^{* * *} \\
(-3.59)\end{array}$ \\
\hline toi & & & & $\begin{array}{c}-0.019^{* * * *} \\
(-7.80)\end{array}$ \\
\hline $\operatorname{tax}$ & & & & $\begin{array}{l}0.003^{* *} \\
(2.46)\end{array}$ \\
\hline net & & & & $\begin{array}{c}-0.005^{* * *} \\
(-2.67)\end{array}$ \\
\hline ship & & & & $\begin{array}{c}-0.006^{* * *} \\
(-2.96)\end{array}$ \\
\hline cons & & & & $\begin{array}{l}0.250^{* * *} \\
(16.09)\end{array}$ \\
\hline
\end{tabular}

Note. The values in parentheses are t statistics. $* * *, * *$ and $*$ indicate significant at the $1 \%, 5 \%$, and $10 \%$ levels respectively.

The lower part of Table 3 shows the regression results in the trade inefficiency model. It can be found that the coefficient of political stability and government efficiency is negative but not significant. It may be because China frequently exports to some countries in West Asia and South Asia that are politically unstable. Therefore, the promotion effect of these two variables on export efficiency has not been fully exerted. The coefficient of signing a free trade agreement is significantly negative, which means that the signing of a free trade agreement can promote the development of bilateral trade activities. The coefficient of trade openness is significantly negative, indicating that the trade openness of countries along the route will increase China's exports of its equipment manufacturing products. The coefficient of tariff level is significantly positive, indicating that the higher the tariff level of countries along the route, the more unfavorable China's bilateral trade with them. In terms of infrastructure, the signs of communication base facilities and transportation infrastructure are both significantly negative, indicating that good infrastructure construction can effectively reduce the inefficiency of trade and promote China's exports to other countries.

\subsection{Measurement and Analysis of Export Efficiency}

\subsubsection{Overall Trade Export Efficiency}

Export trade efficiency refers to the ratio of actual export volume to potential export volume under certain resource endowment conditions. According to equation 3, we separately measured China's export efficiency to countries along the Belt and Road, as shown in Table 4. China's average export trade efficiency to countries along the Belt and Road is 0.302 , indicating that China's export trade of equipment manufacturing products to countries along the road only reaches $30.2 \%$ of the frontier level (potential export volume). This may be because the equipment manufacturing industry has obvious obstacles to export trade, such as political instability and frequent wars in the countries along the route. In addition, most of the countries along the Belt and Road are underdeveloped countries, and the degree of trade openness is not high. This is also one of the reasons why China's overall export efficiency to the countries along the Belt and Road is low.

Among the countries along the Belt and Road, Singapore, the United Arab Emirates, Hungary, Jordan, and Cyprus rank among the top 5 countries in terms of export trade efficiency of China's equipment manufacturing 
products. Singapore and China share the same language and culture, which greatly promotes the export of Chinese equipment manufacturing products. In addition, the export efficiency values of China and the countries along the Belt and Road are quite different. The lowest efficiency value is only 0.079 , and the highest efficiency value is 0.868 .

Table 4. Export trade efficiency between China and countries along the Belt and Road

\begin{tabular}{|c|c|c|c|c|c|}
\hline Countries & Average export efficiency & Rank & Countries & Average export efficiency & Rank \\
\hline Singapore & 0.868 & 1 & Albania & 0.240 & 30 \\
\hline UAE & 0.716 & 2 & Iraq & 0.236 & 31 \\
\hline Hungary & 0.707 & 3 & Romania & 0.223 & 32 \\
\hline Jordan & 0.583 & 4 & Israel & 0.219 & 33 \\
\hline Cyprus & 0.576 & 5 & Philippines & 0.218 & 34 \\
\hline Kyrgyzstan & 0.572 & 6 & Iran & 0.213 & 35 \\
\hline Czech Republic & 0.558 & 7 & Indonesia & 0.208 & 36 \\
\hline Vietnam & 0.530 & 8 & Turkmenistan & 0.206 & 37 \\
\hline Aisha Neil & 0.513 & 9 & Greece & 0.205 & 38 \\
\hline Malaysia & 0.490 & 10 & Oman & 0.201 & 39 \\
\hline Slovakia & 0.452 & 11 & Saudi Arabia & 0.199 & 40 \\
\hline Tajikistan & 0.438 & 12 & Croatia & 0.194 & 41 \\
\hline Slovenia & 0.428 & 13 & Belarus & 0.186 & 42 \\
\hline Cambodia & 0.417 & 14 & Turkey & 0.184 & 43 \\
\hline Latvia & 0.410 & 15 & Pakistan & 0.178 & 44 \\
\hline Latvia... & 0.375 & 16 & Uzbekistan & 0.173 & 45 \\
\hline Maldives & 0.366 & 17 & Moldova & 0.158 & 46 \\
\hline Lebanon & 0.353 & 18 & Kuwait & 0.157 & 47 \\
\hline Georgia & 0.347 & 19 & Russia & 0.148 & 48 \\
\hline Yemen & 0.345 & 20 & Kazakhstan & 0.146 & 49 \\
\hline Ukraine & 0.345 & 21 & Bangladesh & 0.146 & 50 \\
\hline Thailand & 0.333 & 22 & Macedonia & 0.122 & 51 \\
\hline Laos & 0.333 & 23 & Qatar & 0.122 & 52 \\
\hline Laos... & 0.319 & 24 & Armenia & 0.112 & 53 \\
\hline Myanmar & 0.272 & 25 & India & 0.100 & 54 \\
\hline Brunei & 0.262 & 26 & Bosnia and Herzegovina & 0.086 & 55 \\
\hline Bulgaria & 0.261 & 27 & Afghanistan & 0.085 & 56 \\
\hline Bahrain & 0.255 & 28 & Azerbaijan & 0.081 & 57 \\
\hline Sri Lanka & 0.245 & 29 & Nepal & 0.079 & 58 \\
\hline
\end{tabular}

\subsubsection{Annual Export Trade Efficiency}

According to the calculation formula of export trade efficiency, we calculated the export efficiency by year. The result is shown in Figure 1. China's export trade efficiency is on the rise. From 2006 to 2008, China's export efficiency gradually improved. In 2006, the export efficiency value was 0.24 , which rose to the highest point of 0.32 within two years. After the outbreak of the 2008 financial crisis, China's export efficiency peaked in 2009, with an export trade efficiency value of only 0.27 , indicating that China's export trade to the region only reached $27 \%$ of the frontier level. From 2009 to 2014, the efficiency of export trade increased steadily, and from 2014 to 2018, it showed a "v"-shaped trend.

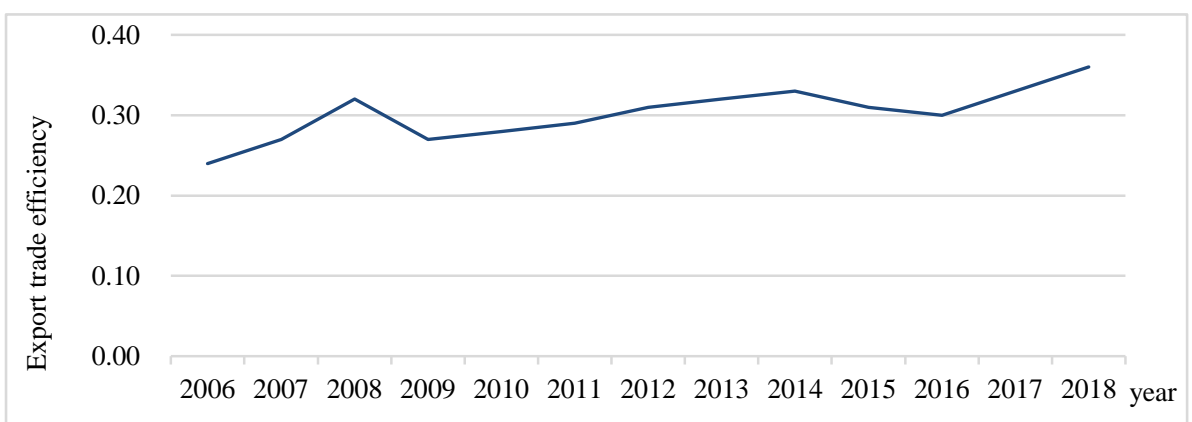

Figure 1. The average export efficiency of China's equipment manufacturing industry to countries along the Belt and Road from 2006 to 2018 


\subsection{Calculation and Analysis of Export Potential}

We calculate the trade potential of countries along the Belt and Road according to equation 4, and visually show the trade development space of both parties from the perspective of flow. After the Belt and Road Initiative was put forward, trade between China and countries along the route increased. We have calculated the export trade potential of equipment manufacturing products from 2013 to 2018, and analyzed China's export potential of equipment manufacturing products to countries along the Belt and Road in 2018 based on the BCG model.

Table 5. China's export potential of equipment manufacturing products from countries along the Belt and Road

\begin{tabular}{cccc}
\hline Year & Actual Export Trade & Export trade potential & multiple \\
\hline 2013 & 2556.19 & 8001.87 & 3.13 \\
2014 & 2856.69 & 8638.65 & 3.02 \\
2015 & 2818.31 & 9166.41 & 3.25 \\
2016 & 2704.52 & 9039.09 & 3.34 \\
2017 & 3051.65 & 9363.22 & 3.07 \\
2018 & 3411.53 & 9354.96 & 2.74 \\
\hline
\end{tabular}

Table 5 compares the export potential of China's equipment manufacturing products to countries along the route since the Belt and Road Initiative was proposed. The overall potential export value shows an upward trend, indicating that China's export trade with countries along the route still has great potential.

We take 2018 China's export trade potential to countries along the Belt and Road as an example, and use the BCG matrix model to analyze the export efficiency and potential to countries along the route. The BCG matrix model analyzes the two dimensions of scale and efficiency. Based on this, the countries along the route can be divided into the following four categories: (1) Star countries with "double high" export efficiency and potential. (2) Taurus countries with high export efficiency but low potential. (3) Problem countries with low export efficiency but great potential. (4) Skinny dog countries with "double low" export efficiency and potential. For "star countries", we maintain the status quo. For "Taurus countries", we should actively expand the scale of trade. For "problem countries", we should analyze the causes of low trade efficiency and solve them. Regarding the "skinny dog country", it may not be considered for the time being. The average value is used as the dividing standard. The average export efficiency is 0.365 and the average export potential is $\$ 21.093$ billion. The specific results are shown in Table 6.

Table 6. The export potential of China and specific countries along the Belt and Road in 2018

\begin{tabular}{|c|c|c|c|c|c|}
\hline country & Export trade efficiency & Export trade potential & country & Export trade efficiency & Export trade potential \\
\hline Afghanistan & 0.097 & 28.068 & Lebanon & 0.408 & 20.145 \\
\hline Albania & 0.356 & 6.154 & Lithuania & 0.419 & 21.280 \\
\hline Armenia & 0.192 & 8.319 & Malaysia & 0.512 & 473.624 \\
\hline Azerbaijan & 0.089 & 37.869 & Maldives & 0.855 & 2.544 \\
\hline Bahrain & 0.311 & 14.956 & Myanmar & 0.306 & 131.719 \\
\hline Bangladesh & 0.186 & 278.161 & Nepal & 0.113 & 39.006 \\
\hline Belarus & 0.229 & 29.625 & Oman & 0.270 & 39.283 \\
\hline Bosnia and Herzegovina & 0.087 & 7.167 & Pakistan & 0.227 & 330.079 \\
\hline Brunei & 0.853 & 12.393 & Philippines & 0.289 & 442.627 \\
\hline Bulgaria & 0.313 & 25.162 & Poland & 0.437 & 290.233 \\
\hline Cambodia & 0.614 & 22.557 & Qatar & 0.148 & 73.688 \\
\hline Croatia & 0.244 & 23.847 & Moldova & 0.147 & 4.313 \\
\hline Cyprus & 0.383 & 10.838 & Romania & 0.292 & 100.528 \\
\hline Czech Republic & 0.786 & 134.859 & Russia & 0.199 & 1230.952 \\
\hline Estonia & 0.573 & 12.228 & Saudi Arabia & 0.213 & 325.162 \\
\hline Georgia & 0.527 & 9.362 & Singapore & 0.822 & 339.988 \\
\hline Greece & 0.281 & 97.267 & Slovakia & 0.435 & 51.066 \\
\hline Hungary & 0.622 & 83.178 & Slovenia & 0.684 & 20.535 \\
\hline India & 0.115 & 3622.259 & Sri Lanka & 0.266 & 57.902 \\
\hline Indonesia & 0.250 & 823.508 & Tajikistan & 0.375 & 14.411 \\
\hline Iran & 0.209 & 389.920 & Macedonia & 0.143 & 4.850 \\
\hline Iraq & 0.283 & 120.680 & Thailand & 0.419 & 489.642 \\
\hline
\end{tabular}




\begin{tabular}{|c|c|c|c|c|c|}
\hline Israel & 0.269 & 126.556 & Turkey & 0.167 & 555.619 \\
\hline Jordan & 0.607 & 16.315 & Turkmenistan & 0.052 & 32.651 \\
\hline Kazakhstan & 0.153 & 273.954 & Ukraine & 0.483 & 75.736 \\
\hline Kuwait & 0.223 & 63.977 & UAE & 0.767 & 204.489 \\
\hline Kyrgyzstan & 0.572 & 11.800 & Uzbekistan & 0.283 & 78.560 \\
\hline Laos & 0.330 & 26.415 & Vietnam & 0.863 & 440.923 \\
\hline Latvia & 0.425 & 14.324 & Yemen & 0.382 & 11.007 \\
\hline
\end{tabular}

As can be seen from the above table, nearly half of the countries along the Belt and Road are skinny dogs. The "star countries" are Malaysia, Singapore, Poland, Thailand, UAE and Vietnam. These countries have high trade efficiency and great trade potential. China should continue to strengthen trade relations with them. The "Taurus countries" represented by Cyprus, Georgia, and Hungary have high trade efficiency but low trade potential. China needs to pay attention to the advantages of high efficiency and expand the scale of trade with these countries. In addition, there are some countries with low trade efficiency but great trade potential, such as Russia, India and Bangladesh. The main reason for the low export efficiency is the imperfect institutional environment, infrastructure and trade openness. Therefore, China and these countries should strengthen the Belt and Road cooperation and promote the improvement of infrastructure and investment environment in these countries, so that "problem countries" become important potential markets and promote China's exports.

\section{Conclusions and Policy Implications}

\subsection{Conclusions}

Based on the stochastic frontier gravity model, this paper uses the "one-step method" to estimate the impact of trade inefficiencies on export trade, and calculates the trade efficiency of China's export of equipment manufacturing products to countries along the Belt and Road from 2006 to 2018, and then analyzes the trade potential. The main conclusions are as follows:

1) Economic scale, population scale, and geographic distance have a significant positive effect on export trade. Among these factors, the economic scale of China and its trading partners is the most critical. An increase in the population of partner countries will promote China's exports, while the size of China's population has the opposite effect. Distance is still one of the important reasons that restrict China's trade with countries along the Belt and Road. The greater the distance between the two countries, the more unfavorable the development of trade.

2) A better trading environment and infrastructure will help improve trade efficiency. The main factors affecting the efficiency of China's export of equipment manufacturing products to countries along the Belt and Road are the institutional environment, free trade agreements, trade openness and infrastructure. Improvements in partner government efficiency and governance can help increase China's exports. The signing of a free trade agreement provides convenient terms of trade for both sides of the trade and helps to improve the efficiency of China's export of equipment manufacturing products to countries along the route. The high degree of trade openness and good infrastructure conditions of trading partners have created a favorable export environment and improved China's export efficiency.

3) China's export trade to countries along the Belt and Road is inefficient but has huge potential. According to the measurement results of export trade efficiency and its potential, China's overall export efficiency of equipment manufacturing products from countries along the route is low, not exceeding $40 \%$. Moreover, the efficiency of export trade to different countries is significantly different. The lowest efficiency is Nepal at 0.079 and the highest efficiency is Singapore at 0.868. In general, there is a lot of room for improvement in China's exports of equipment manufacturing products to countries along the Belt and Road.

\subsection{Policy Implications}

Based on the above conclusions, we propose the following suggestions:

1) Strengthen international trade cooperation. The implementation of the Belt and Road Initiative has brought new ideas to resolve the overcapacity of the domestic equipment manufacturing industry and provided new opportunities for its development. Currently, the United States, Hong Kong and other regions are the main exporters of China's equipment manufacturing products, and the market potential of the One Belt One Road has not been fully tapped. Therefore, comprehensively considering comparative advantages and trade intensity, China should attach importance to countries with comparative advantages (such as Hungary and Slovakia), increase export trade, and make full use of existing conditions to strengthen relations with countries with a 
higher trade integration index. China should actively carry out trade cooperation activities with countries along the Belt and Road to establish stable economic relations. For some countries that have not established a free trade zone, China can consider opening up a path of trade cooperation in terms of investment, technology, and efficiency.

2) Actively improve the terms of trade. It can be seen from the empirical results of trade inefficiency that the degree of trade openness, institutional environment and infrastructure are the main reasons affecting export efficiency. Therefore, it is necessary to actively invest in the infrastructure construction of the countries along the Belt and Road, including the improvement of transportation, energy and communications and other hardware facilities. On the other hand, China should carry out more political, economic and cultural exchanges with partner countries, deepen cooperation along the Belt and Road, and increase the trade openness of countries along the route.

3) Pay attention to the differentiation of the export market. China should adopt targeted market strategies for different types of markets: First, for "star countries" such as Singapore, the UAE, and Vietnam, which have large export scales and high efficiency, "seek progress while maintaining stability" should be chosen to improve the overall level of equipment manufacturing industry trade. Second, for some countries with large scale of trade but low trade efficiency, China should focus on the artificial hindrances of low export efficiency and help them solve the problems in transportation, trade and investment facilitation. Third, strengthen trade ties with "Taurus countries", such as Cyprus, Georgia and Hungary, and use the advantages of high export efficiency to open up export potential and expand the scale of bilateral trade. Finally, we should pay attention to those temporarily immature markets and actively tap the export potential.

\subsection{Research Limitations}

Finally, this article only measures the export trade potential of China's equipment manufacturing industry to countries along the Belt and Road. If import potential and export potential are included in the analysis framework at the same time, the research may be more complete.

\section{Acknowledgements}

This work is supported by the National Social Science Foundation of China (No.19BJY003) and the Education Department Foundation of Guangdong Province (No.GWTP-GC-2017-02).

\section{References}

Armstrong, S. P. (2007). Measuring Trade and Trade Potential: A Survey. Asia Pacific Economic Papers, 368, 1-18. https://doi.org/10.2139/ssrn.1760426

Battese, G. E., \& Coelli, T. J. (1995). A Model for Technical Inefficiency Effects in a Stochastic Frontier Production Function for Panel Data. Empirical Economics, 20, 325-332. https://doi.org/10.1007/BF01205442

Beckerman, W. (1956). Distance and the pattern of intra-European trade. The Review of Economics and Statistics, 31-40. https://doi.org/10.2307/1925556

Cheng, L. (2018). Analysis of China's export efficiency to countries along the "Belt and Road": Based on the Stochastic Frontier Gravity Model. East China Economic Management, 32, 40-48. https://10.19629/j.cnki.34-1014/f.171010026

Dang, Z. (2020). Forecast of China's trade efficiency and potential for agricultural exports to countries along the "Belt and Road". Journal of Northwest A\&F University (Social Science Edition), 20, 128-136 . https://10.13968/j.cnki.1009-9107.2020.01.15

Fuchs, M., \& Wohlrade, K. (2005). The European Union's trade potential after the enlargement in 2004. IFO working papers, 2005. https://www.econstor.eu/handle/10419/73737

Gao, Z. (2015). Research on the Potential and Efficiency of Bilateral Trade in the Construction of China-Pakistan Economic Corridor_ Based on the Analysis of Stochastic Frontier Gravity Model. Finance and Economics, 11, 101-110. https://10.3969/j.issn.1000-8306.2015.11.010

Hou, D. (2017). Research on Trade Efficiency and Potential between China and Central and Eastern European Countries_-Analysis Based on Stochastic Frontier Gravity Model. Shanghai Economic Research, 07, 105-116. https://10.19626/j.cnki.cn31-1163/f.2017.07.011

Isard, W., \& Peck, M. J. (1954). Location Theory and International and Interregional Trade Theory. The Quarterly Journal of Economics, 68, 97-114. https://doi.org/10.2307/1881920 
Kalirajan, K. (1999). Stochastic varying coefficients gravity model: An application in trade analysis. Journal of Applied Statistics, 26, 185-193. https://doi.org/10.1080/02664769922520

Li, L. (2019). Research on the Export Trade Potential and Trade Efficiency of my country's Equipment Manufacturing Products_-An Empirical Study Based on the "One Belt One Road" Countries. International Trade Issues, 01, 80-92. https://10.13510/j.cnki.jit.2019.01.007

Li. (2017). Analysis on the export flow and potential of China's high-tech products to Arab countries under the background of the "Belt and Road Initiative". Statistics and Information Forum, 32, 99-105. https://10.3969/j.issn.1007-3116.2017.06.015

Linnemann, H. (1966). An econometric study of international trade flows. The Economic Journal, 306, 366-368. https://doi.org/10.2307/2229319

Lu, Z. (2010). China's export potential and its influencing factors: Estimation based on the stochastic frontier gravity model. Quantitative and Technical Economic Research, 27, 21-35. https://10.13653/j.cnki.jqte.2010.10.006

Nilsson, L. (2000). Trade integration and the EU economic membership criteria. European Journal of Political Economy, 16, 807-827. https://doi.org/10.1016/S0176-2680(99)00060-9

Pöyhönen, P. (1963). A tentative model for the volume of trade between countries. Weltwirtschaftliches Archiv, 90, 93-100. https://www.jstor.org/stable/40436776

Ravishankar, G., \& Stack, M. M. (2014). The Gravity Model and Trade Efficiency: A Stochastic Frontier Analysis of Eastern European Countries' Potential Trade. The World Economy, 37, 690-704. https://doi.org/10.1111/twec.12144

Reifschneider, D., \& Stevenson, R. (1991). Systematic departures from the frontier: A framework for the analysis of firm inefficiency. International Economic Review, 32, 715-723. https:// 10.2307/2527115

Tamini, L. (2016). Trade Performance and Potential of North African Countries: An Application of a Stochastic Frontier Gravity Model. Cahiers De Recherche Create, 4,1-37. https://doi.org/10.2139/ssrn.3265453

Tan, Z. (2015). The 21st Century "Maritime Silk Road" Trade Potential and Its Influencing Factors_—An Empirical Study Based on Stochastic Frontier Gravity Model. International Trade Issues, 02, 3-12. https://10.13510/j.cnki.jit.2015.02.001

Tang, Shao, Li, etc. (2018). China's export trade potential to countries along the "Belt and Road". Economic Geography, 38, 30-37. https://10.15957/j.cnki.jjdl.2018.09.004

Tinbergen, J. (1962). Shaping the World Economy: Suggestions for an International Economic Policy. New York: The Twentieth Century Fund. https://doi.org/10.2307/1236502

Viorica, E. D. (2015). Econometric Analysis of Foreign Trade Efficiency of E.U. Members Using Gravity Equations. Procedia Economics and Finance, 20, 670-678. https://doi.org/10.1016/S2212-5671(15)00122-7

Wang, H. J., \& Schmidt, P. (2002). One-step and Two-step Estimation of the Effects of Exogenous Variables on Technical Efficiency Levels. Journal of Productivity Analysis, 18, 129-144. https://10.1023/A:1016565719882

Wang, W. (2016). The trade potential of the Silk Road Economic Belt_— Analysis based on the "natural trading partner" hypothesis and the stochastic frontier gravity model. Economist, 04, 33-41. https://10.16158/j.cnki.51-1312/f.2016.04.005

Wang, Y. (2019). The impact and potential analysis of language distance on China's export trade to West Asia and North Africa from the perspective of regional countries. Journal of Shanghai University of International Business and Economics, 26, 99-108. https://10.16060/j.cnki.issn2095-8072.2019.02.009

Wang. (2017). Analysis of China's export potential to countries along the "Belt and Road" and its influencing factors. Business Economics and Management, 02, 51-59. https://10.14134/j.cnki.cn33-1336/f.2017.02.006

Yin, L. (2019). Research on my country's Export Potential and Export Efficiency of Electrical Equipment Manufacturing Products in "One Belt and One Road" Countries. Industrial Technology Economy, 38, 3-9. https://10.3969/j.issn.1004-910X.2019.08.001

Zhang, Y. (2018). The efficiency and influencing factors of China's export trade to the "Belt and Road" countries. Journal of Capital University of Economics and Business, 20, 39-48. https://10.13504/j.cnki.issn1008-2700.2018.05.005 
Zhang. (2017). Research on the trade potential between China and the areas along the "Belt and Road". International Trade Issues, 07, 85-95. https://10.13510/j.cnki.jit.2017.07.008

Zong, W. (2018). Trade potential and trade efficiency between China and the countries along the "Belt and Road": Empirical investigation based on night light data. Journal of Zhongnan University of Economics and Law, 06, 125-133. https://10.19639/j.cnki.issn1003-5230.2018.0087

\section{Notes}

Note 1. The 58 countries are as follows: Including 5 countries in Central Asia, Kazakhstan, Kyrgyzstan, Tajikistan, Uzbekistan and Turkmenistan. Including 10 countries in Southeast Asia, they are Malaysia, Vietnam, Laos, Philippines, Myanmar, Indonesia, Thailand, Singapore, Brunei and Cambodia. Including 7 countries in South Asia, they are India, Pakistan, Bangladesh, Afghanistan, Sri Lanka, Maldives and Nepal. Including 14 countries in Central and Eastern Europe, they are Poland, Czech Republic, Slovakia, Slovenia, Romania, Bulgaria, Macedonia, Bosnia and Herzegovina, Albania, Estonia, Lithuania, Latvia, Hungary, Croatia. Including 15 countries in West Asia, they are Turkey, Iran, Iraq, UAE, Lebanon, Oman, Yemen, Jordan, Israel, Saudi Arabia, Qatar, Bahrain, Kuwait, Cyprus, Greece. And Russia, Ukraine, Belarus, Georgia, Azerbaijan, Armenia, Moldova, which belong to the 7 CIS countries.

\section{Copyrights}

Copyright for this article is retained by the author(s), with first publication rights granted to the journal.

This is an open-access article distributed under the terms and conditions of the Creative Commons Attribution license (https://creativecommons.org/licenses/by/4.0/). 